\title{
MONITORING TRICHLORFON AND AFLATOXINS RESIDUES IN EGGS OF CHICKENS
}

\author{
Ahmed, E.E.K..*; Abdel Aziz, A.T. ${ }^{* *}$ and Arafa, M.M.* \\ * Biochemistry Dept., Animal Health Research Institute, Dokki \\ ** Food Hygiene Dept., Animal Health Research Institute, Dokki
}

Received at $1-2-2003$

\begin{abstract}
The present study was carried out to evaluate the correlation between the excretion of aflatoxin $B_{1}$ residues in eggs of laying hens fed aflatoxin $B_{1}$-contaminated ration and excretion of trichlorfon pesticide after farm spray with trichlorfon pesticide. 7 egg samples were collected daily for 7 days from laying hens fed on ration contained $15 \mathrm{ppb}$ aflatoxin $B_{1}$ within, from farm previously sprayed with trichlorfon pesticide (0.15\%) for eradication of ticks. In this work, number and percentage of eggs contained aflatoxin B1 increased was increasing with time in both albumin and yolk till reached 100\% after 3 days of hens trichlorfon exposure. Vice versa, number and percentage of eggs contained trichlorfon residues were higher directly after spraying then completely disappeared from yolk and albumin after 7 days. Aflatoxin $B_{1}$ residues significantly increased comparing with time in albumin and insignificantly elevated in yolk, allover the experimental period. Otherwise, trichlorfon residues significantly dropped in both albumin and yolk till became undetectable at the $7^{\text {th }}$ day. This study indicated that there are significant correlation between aflatoxin $B_{1}$ and trichlorfon residues in albumin and yolk of tested egg samples. These results indicated the emphasizing importance of controlling aflatoxin levels in rations for laying hens especially when using pesticide for controlling ticks. Also, the withdrawal time for trichlorfon in eggs was observed to be 6 days. In addition, health significance about aflatoxin $B_{1}$ and trichlorfon residues in egg have been discussed.
\end{abstract}




\section{INTRODUCTION}

Pollution with chemical pesticides is considered as one of the most important environmental problems facing humans. The intensive use of pesticides to eliminate pests or to regulate crop growth has led to pesticide residues in soils, air, water, stored grains, crops, plants and rations at concentration levels which exceed the legal limits (Süsse and Müller, 1996). In last decade organophosphate (OP) pesticides were produced and entered the environment in greater quantities than do other pesticides Rossi et al. (2001).

Human exposure to pesticide residues can occur as a consequence of the use of a pesticide on animals or their feed if the residues transfer to the animal commodities that humans consume. Environmental Protection Agency (EPA) examined the potential for the transfer of OP residues from animal feeds to human foods and from the direct application of the OP to an animal. The residue monitoring for OP residues in eggs (only 1 sample was detected out of approximately 1,300 samples analyzed by FDA's Surveillance Program for multiple OPs from 1992-1998), (FDA, 2002).

Trichlorfon is an organophosphate insecticide used for the control of household, agricultural, and farm animal insect pests. It is an inhibitor of cholinesterase and produces neurotoxic effects in human and animals. Human exposure occurs mainly as a result of agricultural or veterinary practices (EHC 132, 1992 and $\boldsymbol{U S E P A}, 1999)$. Uses of trichloroforn in controlling flies in and around poultry houses (poultry house, egg room, and feed room) have been recorded and used allover the world (Hoelscher, 2000). Otherwise, residues of trichlorfon in eggs from treated hens have been found to contain $0.05 \mathrm{mg}$ trichlorfon $/ \mathrm{kg}$ (IPCS, 1991). Although, no maximum tolerance for trichlorfon residues in eggs have been recorded (FAO/WHO, 1989; IPCS, 1991; EPA, 1999 and FAO/WHO, 2001). Otherwise, percent of egg samples without pesticide residues was recorded to be $75 \%$ in samples from different governorates (Food and Drug Administration Pesticide Program, 1997) 
Many hazards of mycotoxins affected the human health. Aspergillus flavus typically produces aflatoxins $\mathrm{B}_{1}$ and $\mathrm{B}_{2}$ where as Asperiglius parasiticus produces aflatoxins $\mathrm{B}_{1}, \mathrm{~B}_{2}, \mathrm{G}_{1}, \mathrm{G}_{2}$ (Pitt, 1989). Aflatoxin $\mathrm{B}_{1}$ most commonly found in agricultural commodities, is the most potent carcinogen for experimental animals found in the world and may be related to human hepatocancer (Tetushia, 1990). Because of human health concern, many countries set tolerances for some mycotoxins in foods and feeds, and the number of regulations concerning mycotoxins is increasing (Tetushia, 1990).

Food can be contaminated by aflatoxins either directly by fungal growth or indirectly carrying over of the residues of toxins from feed to food of animal origin such as meat, milk, and eggs (Maertlbaner, et al., 1991). Eggs are considered a major component of children as well as adult diet. Detection of aflatoxin $\mathrm{B}_{1}$ in marketed eggs in Egypt have been recorded (Samia et al., 2001).

Excretion of aflatoxin $\mathrm{B}_{1}$ via eggs have been studied ( $\boldsymbol{A} \boldsymbol{b \boldsymbol { d }} \mathbf{E l}$ Hamid and Dorra, 1990; Oliveria et al., 2000 and Samia et al., 2001) but the correlation between its excretion and pesticide exposure did not find the same importance. So, the objective of the present study is to determine the presence of trichlorfon pesticide after its application in laying hen farms as well as aflatoxin $\mathrm{B}_{1}$ which detected in ration of hens in eggs till pesticide disappear, also studying the relation between presence of pesticide and aflatoxin $\mathrm{B}_{1}$ residues in eggs.

\section{Material \& Methods}

Samples:7 eggs were collected daily from laying hen farm directly after spraying trichlorfon in the farm for 7 successive days.

Pesticide: Trichlorfon (Meterifonat $\left.{ }^{\circledR}\right)$ is an organophosphorus pesticide produced by ADWIA company. It is colourless crystalline powder, stable at room temperature. Its chemical structure is dimethyl 2, 2, 2, -trichloro- 1- hydroxyethylphosphonate (Worthing and Walker, 1987 and Marquardt, et al., 1999). 
Pesticide was applied in farm flocks by recommended dose $(0.15 \%)$ and sprayed on earth and floor for tick eradication according to company recommendation (Worthing and Walker, 1987).

Pesticide residue analysis: Trichlorofon was extracted from egg yolk or egg albumin using acetonitrile (WHO, 1992). Then a multiresidue method is described for determination of trichlorfon, samples were extracted through a selective Extraelut column with methylene chloride and cleaned up with quaternary aminesilane-silica-dichloromethane. Extracts were then analyzed by gas chromatography (GC) (Bicchi et al., 1997).

\section{Aflatoxin determination:}

Aflatoxin $\mathrm{B}_{1}\left(\mathrm{AFB}_{1}\right)$ was firstly recognized by thin layer chromatography according to Schuller and Van-Egmond (1981). Then, aflatoxin was extracted from contaminated tissues with methanol the extract was purified and concentrated for qualitative estimation of the toxin. Aflatoxin in positive samples was estimated quantitatively by a fluorimetric method according to $A O A C$ (1990). Samples were prepared by mixing with an extraction solution, blending and filtration. The extract was then applied to the Afla Test column. At this stage, the aflatoxin binds to the antibody on the column. The column is then washed with water to get rid off the immunoaffinity column impurities. Aflatoxin content was then measured by a fluorometer.

\section{Statistical analysis:}

Data obtained were statistically analysed used analysis of variance (ANOVA) and comparing between groups were performed using least significant difference (LSD) and Duncan Multiple Range test for comparative of mean at $\mathrm{P}<0.05$. Also, Using Pearson correlation was performed at $\mathrm{P}<0.05$ and $\mathrm{P}<0.01$ according to Petrie and Watson (1999) and computerized using SPSS 11 (2001). 


\section{RESULTS}

Table (1) shows the results of ration analysis which used in feeding of broiler chicken contained 15 ppb of aflatoxin $\mathrm{B}_{1}$, while ochratoxin did not extract from ration. Biochemical constitutes was within acceptable limits for broiler chickens.

Table(2) shows number and percentage of positive samples for aflatoxin $\mathrm{B}_{1}$ and trichlorfon residues in albumin and yolk of eggs. Concerning aflatoxin $\mathrm{B}_{1}$, this table showed increase in number and percentage of positive samples from first days $(71.4 \%$ in albumin \& $57.1 \%$ in yolk) to second days (85.7\% in both albumin and yolk) to $100 \%$ in both albumin and yolk form the third day till the end of the experimental period after exposure to trichlorfon. On the contrary, decrease in percentage of trichlorfon was observed with passing of exposure time till completely disappear after 7 days.

Using ANOVA test and LSD, significant increase $(\mathrm{P}<0.05)$ in aflatoxin $\mathrm{B}_{1}$ content in albumin accompanied by non-significant change in yolk allover the experimental period was observed (Table, 3 and Fig., $1)$. Otherwise, significant decrease $(\mathrm{P}<0.05)$ in trichlorfon residues in both albumin and yolk from the first day of experiment till the six day which completely undetected at the seventh day using ANOVA test and LSD was recorded (Table, 3 and Fig., 2).

Duncan multiple range test for comparative of means showed consequently significance difference (increase) in aflatoxin $\mathrm{B}_{1}$ concentration in egg albumin subgrouping, where the mean at day 1 was significantly differ from days 2 and 3 then from days 3, 4, $5 \& 6$ and finally from days 5 till 7 (Table, 4).

Concerning, aflatoxin $\mathrm{B}_{1}$ concentration in egg yolk subgrouping Duncan multiple range test for comparative of means showed insignificant difference at $\mathrm{P}<0.05$ allover the experimental periods

Table(6) demonstrates that Duncan multiple range test for

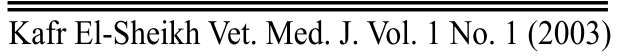


comparative of means indicate consequently significance (decrease) in three subgrouping manner difference in trichlorfon residues in egg albumin, where the mean at day 1 was significantly differ from days 2, 3 and 4 and lastly from days 5, 6 and 7 (Table, 6).

Duncan multiple range test for comparative of means showed consequently significance differences (drop) in trichlorfon residues in egg yolk in 3 subgrouping, where the mean at days 1, 2, 3, 4 was significantly differ from days 2,3., 4 and 5 followed by days 6 and 7 (Table, 7).

Table $(8)$ shows positive significant correlation $(\mathrm{P}<0.01)$ between albumin and yolk in aflatoxin $\mathrm{B}_{1}$ concentration and trichlorfon residue (Using Pearson correlation). Otherwise significantly negative correlation $(\mathrm{P}<0.01)$ observed between aflatoxin $\mathrm{B}_{1}$ concentration in albumin and trichlorfon residues in both albumin and yolk as well as between aflatoxin $\mathrm{B}_{1}$ concentration in yolk comparing with trichlorfon residues in both albumin and yolk but at $\mathrm{P}<0.05$ (Using Pearson correlation).

Table (1): Results of ration analysis.

\begin{tabular}{|c|c|}
\hline Parameter & Percent or Concentration \\
\hline Aflatoxin $\mathrm{B}_{1}$ & $15 \mathrm{ppb}$ \\
\hline Ochratoxin & $-\mathrm{ve}$ \\
\hline Total protein & $20.6 \%$ \\
\hline Fat & $6.4 \%$ \\
\hline Phosphorus & $0.98 \%$ \\
\hline Calcium & $2.1 \%$ \\
\hline Humidity & $11.52 \%$ \\
\hline Ash & $4.8 \%$ \\
\hline Fiber & $4.3 \%$ \\
\hline Carbohydrate & $50.38 \%$ \\
\hline
\end{tabular}




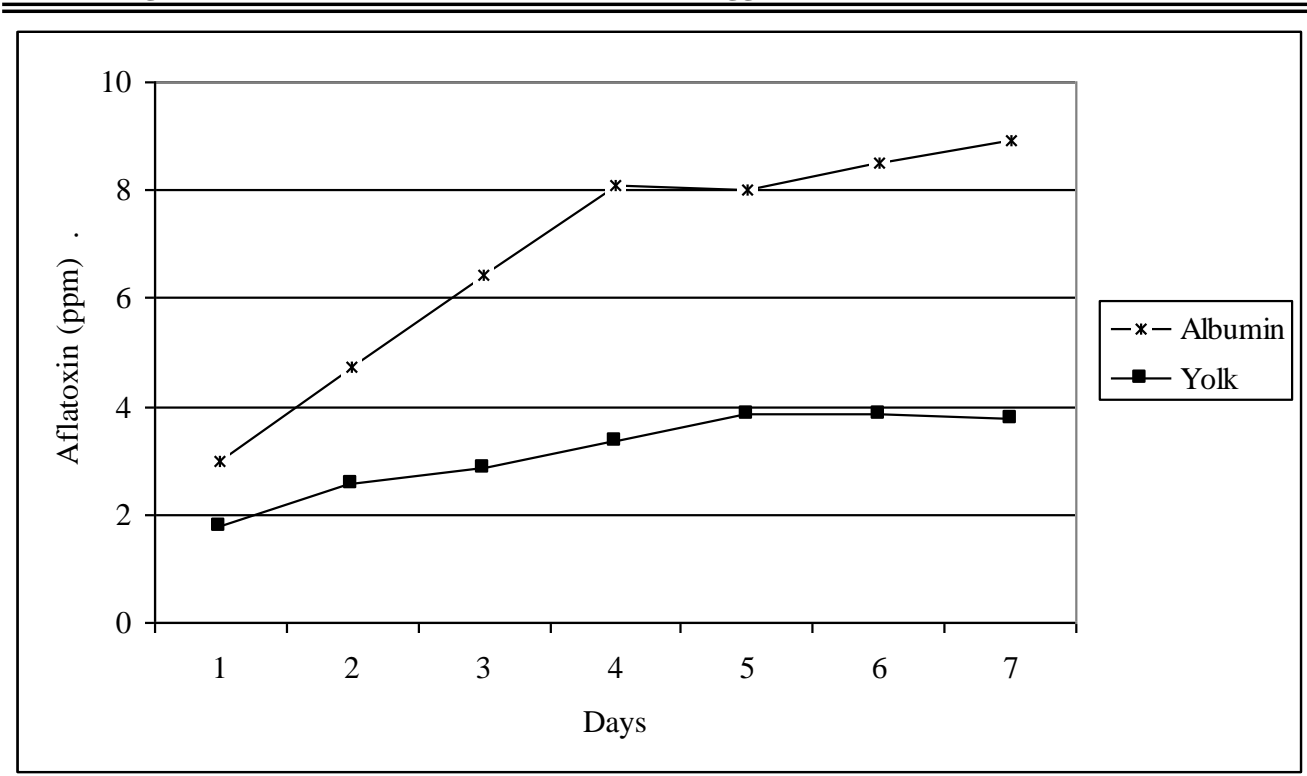

Fig. (1): Illustrates the concentration level of aflatoxin $B_{1}(\mathrm{ppb})$ throughout 7 days.

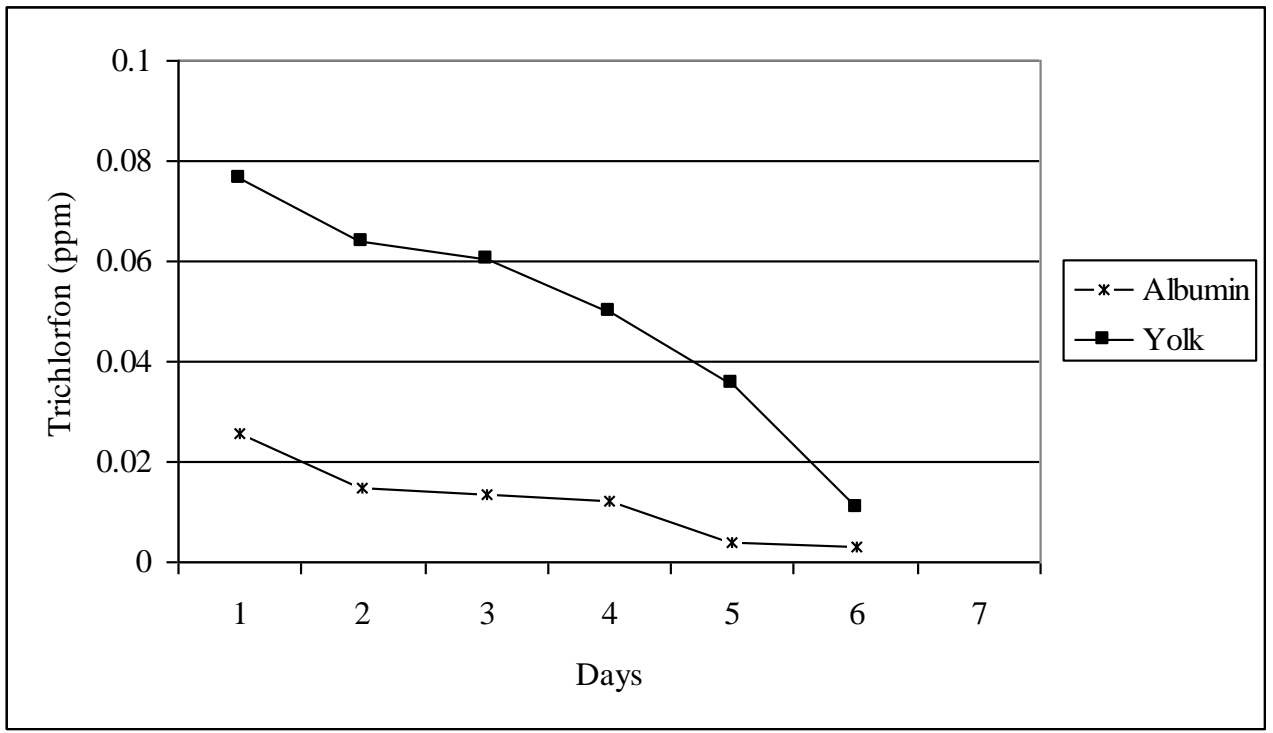

oughout 7 days.

Table (4): Duncan ${ }^{\mathrm{a}, \mathrm{b}}$ multiple range test significance of aflatoxin in egg albumin.

$\overline{\text { Kafr El-Sheikh Vet. Med. J. Vol. } 1 \text { No. } 1 \text { (2003) }}$ 


\begin{tabular}{||c||c||c|c|c|c||}
\hline \hline \multirow{2}{*}{ Day } & \multirow{2}{*}{$\mathbf{N}$} & \multicolumn{4}{|c||}{ Subset for alpha =.05 } \\
\cline { 3 - 6 } & & $\mathbf{1}$ & $\mathbf{2}$ & $\mathbf{3}$ & $\mathbf{4}$ \\
\hline \hline 1.00 & 7 & 3.0000 & & & \\
\hline 2.00 & 8 & & 5.0313 & & \\
\hline 3.00 & 7 & & 6.4286 & 6.4286 & \\
\hline 5.00 & 7 & & & 8.0000 & 8.0000 \\
\hline 4.00 & 7 & & & 8.0857 & 8.0857 \\
\hline 6.00 & 7 & & & 8.5000 & 8.5000 \\
\hline 7.00 & 5 & & & & 8.6800 \\
\hline Sig. & & 1.000 & .170 & .064 & .542 \\
\hline \hline
\end{tabular}

Means for groups in homogeneous subsets are displayed.

a Uses Harmonic Mean Sample Size $=6.735$.

b The group sizes are unequal. The harmonic mean of the group sizes is used. Type I error levels are not guaranteed.

Table (5): Duncan ${ }^{\mathrm{a}, \mathrm{b}}$ multiple range test significance of aflatoxin in egg yolk.

\begin{tabular}{|c||c||c||}
\hline \multirow{2}{*}{ Day } & \multirow{2}{*}{$\mathbf{N}$} & Subset for alpha $=. \mathbf{0 5}$ \\
\cline { 3 - 3 } & & $\mathbf{1}$ \\
\hline \hline 1.00 & 7 & 1.7750 \\
\hline 2.00 & 8 & 2.8571 \\
\hline 3.00 & 7 & 3.2600 \\
\hline 5.00 & 7 & 3.3714 \\
\hline 4.00 & 7 & 3.8083 \\
\hline 6.00 & 7 & 3.8571 \\
\hline 7.00 & 5 & 3.8571 \\
\hline Sig. & & .203 \\
\hline
\end{tabular}

Means for groups in homogeneous subsets are displayed.

a Uses Harmonic Mean Sample Size $=6.735$.

b The group sizes are unequal. The harmonic mean of the group sizes is used. Type I error levels are not guaranteed.

Table (6):Duncan ${ }^{\mathrm{a}, \mathrm{b}}$ multiple range test significance of trichlorfon in egg albumin. 


\begin{tabular}{||c||c||c|c|c||}
\hline \hline \multirow{2}{*}{ Day } & \multirow{2}{*}{$\mathbf{N}$} & \multicolumn{3}{|c||}{ Subset for alpha =.05 } \\
\cline { 2 - 5 } & & $\mathbf{1}$ & $\mathbf{2}$ & $\mathbf{3}$ \\
\hline \hline 1.00 & 7 & .0000 & & \\
\hline 2.00 & 8 & .0030 & & \\
\hline 3.00 & 7 & .0040 & & \\
\hline 5.00 & 7 & & .0123 & \\
\hline 4.00 & 7 & & .0130 & .0255 \\
\hline 6.00 & 7 & & .0135 & 1.000 \\
\hline 7.00 & 5 & .333 & .777 & \\
\hline Sig. & & & & \\
\hline
\end{tabular}

Means for groups in homogeneous subsets are displayed.

a Uses Harmonic Mean Sample Size $=6.735$.

b The group sizes are unequal. The harmonic mean of the group sizes is used. Type I error levels are not guaranteed.

Table(7):Duncan ${ }^{\mathrm{a}, \mathrm{b}}$ multiple range test significance of trichlorfon in egg yolk.

\begin{tabular}{|c||c||c|c|c||}
\hline \multicolumn{1}{|c||}{\multirow{2}{*}{ Day }} & \multirow{2}{*}{$\mathbf{N}$} & \multicolumn{3}{c||}{ Subset for alpha $=.05$} \\
\cline { 2 - 5 } & & $\mathbf{1}$ & $\mathbf{2}$ & $\mathbf{3}$ \\
\hline \hline 1.00 & 7 & .0000 & & \\
\hline 2.00 & 8 & .0110 & & \\
\hline 3.00 & 7 & & .0358 & \\
\hline 5.00 & 7 & & .0502 & .0502 \\
\hline 4.00 & 7 & & .0558 & .0558 \\
\hline 6.00 & 7 & & .0604 & .0604 \\
\hline 7.00 & 5 & & & .0766 \\
\hline Sig. & & .371 & .070 & .052 \\
\hline
\end{tabular}

Means for groups in homogeneous subsets are displayed.

a Ises Harmonic Mean Samnle Size $=6735$

are not guaranteed.

ss is used. Type I error levels

Table(8):Correlation between aflatoxin $\mathrm{B}_{1}$ concentration and pesticide residue in both albumin and yolk of egg (Using Pearson correlation). 


\begin{tabular}{||c|c||c|c||c|c||}
\hline \hline \multirow{2}{*}{\multicolumn{2}{|c||}{ Pearson correlation }} & \multicolumn{2}{c||}{ Aflatoxin $\mathbf{B}_{1}$} & \multicolumn{2}{c||}{ Trichlorfon } \\
\cline { 3 - 6 } & Albumin & Yolk & Albumin & Yolk \\
\hline \hline \multirow{2}{*}{$\begin{array}{c}\text { Aflatoxin } \\
\text { B }_{1}\end{array}$} & Albumin & 1 & $0.417^{* *}$ & $-0.583^{* *}$ & $-0.585^{* *}$ \\
\cline { 2 - 6 } & Yolk & $0.417^{* *}$ & 1 & $-0.288^{*}$ & $-0.344^{*}$ \\
\hline \multirow{2}{*}{\begin{tabular}{c} 
Trichlorfon \\
\cline { 2 - 6 }
\end{tabular}} & Albumin & $-0.583^{* *}$ & $-0.288^{*}$ & 1 & $0.600^{* *}$ \\
\cline { 2 - 6 } & Yolk & $-0.585^{* *}$ & $-0.344^{*}$ & $0.600^{* *}$ & 1 \\
\hline
\end{tabular}

* Correlation is significant at the 0.05 level (2-tailed) using Pearson test.

** Correlation is significant at the 0.01 level (2-tailed) using Pearson test.

\section{DISCUSSION}

The study was planned to spot a light on the importance of excretion of aflatoxin $\mathrm{B}_{1}$ in eggs of laying hens fed aflatoxin $\mathrm{B}_{1}$ contaminated ration and sprayed with trichlorfon pesticide to investigate the correlation between them.

Table (1) shows that the laying flock was fed on a well balanced ration free from ochratoxin residues and contained aflatoxin B1 in concentrations of $(15 \mathrm{ppb})$ within the permissible limits for ration where the maximum permissible limits in rations for domestic non-milkproducing animals was 100 ppb (STATpub.com, 1999 and FDA, 2002).

Follow up the aflatoxin residues in eggs albumin and yolk indicated that both number and percentages increased after pesticide application with more prevalence in egg albumin. While, trichlorfon residues was depleted till disappear completely after 7 days but with more prevalence in yolk (Table, 2).

Although, The observed results concerning aflatoxin residues were contradicted with Abd El-Hamid and Dorra (1990) and Samia et al. (2001) who recorded that in egg collected form markets the aflatoxin in egg yolk higher than egg albumin. Our result are coincided with (Schuller et al., 1983 and FDA, 2002) who explain this observation to the fact that aflatoxin is water soluble not oil soluble Sc th ........ $f$ aflatoxin in albumin higher than in egg yolk.

Concerning trichlorfon, it is fat soluble pesticide (WHO, 1992 and Marquardt et al., 1999) and this could be explained the obtained data Kafr El-Sheikh Vet. Med. J. Vol. 1 No. 1 (2003) 
regarding increase its percentage in egg yolk than egg albumin.

Table (3) demonstrates residues of aflatoxin as well as trichlorfon in albumin and yolk of tested eggs. Concerning to aflatoxin $B_{1}$ concentrations in albumin it was gradually significant increase from 3.0 to $8.91 \mathrm{ppb}$ at the 7 th day using ANOVA test at $\mathrm{P}<0.05$ with Least Significant difference $2.0313 \mathrm{ppb}$ (Table, 3 and Fig., 1). Regarding to aflatoxin $\mathrm{B}_{1}$ content in yolk, it is appeared non significant elevation in its level in yolk allover the experimental period where it rose from 1.78 at the first day to 3.76 at the end of the experiment (Table, 3 and Fig., 1).

The obtained results were nearly similar to that recorded by $\boldsymbol{F u k a l}$ and Sova (1988); Abd El-Hamid and Dorra (1990) who stated that egg yolk contain $10 \mathrm{ppb}$, while egg albumin contain $6 \mathrm{ppb}$ of Aflatoxin and Samia et al. (2001) who recorded that aflatoxin content of egg yolk (19.07 ppb) higher than egg albumin (4.07 ppb) in eggs collected form markets. And appear lower than reports of Wolzak et al. (1985) who stated that level of aflatoxin $\mathrm{B}_{1}$ in eggs was $0.5 \mu \mathrm{g} / \mathrm{kg}$ after feeding diet containing 3310 micrograms of AFB1; Fernadez et al. (1994) recorded the level of aflatoxin B1 in egg as $0.32 \mu \mathrm{g} / \mathrm{kg}$ after feeding aflatoxin in a dose of $5 \mathrm{mg} / \mathrm{kg}$ feed and Oliveira et al. (2000) reported that the average content of aflatoxin $B_{1}(0.1 \mu \mathrm{g} / \mathrm{kg})$ in eggs of chickens fed $500 \mu \mathrm{g} / \mathrm{kg}$ aflatoxin per $\mathrm{kg}$ of feed.

Although, the recorded aflatoxin concentration in this study was less than maximum possible levels of total aflatoxins in human feeds (20 ppb) (STATpub.com, 1999; FDA, 2002 and Nautiyal, 2002) but from human health view it is so important because the eggs is primary feed of children.

Data analysis using Duncan multiple range test for comparative of means at $\mathrm{P}<0.05$ proved gradual significant increase between 4 homogenous subsets between days $1 ; 2 \& 3 ; 3,4,5, \& 6$ and 4, 5, 6 and 7 (Table, 4). Whereas, data analysis using Duncan multiple range test for comparative of means at $\mathrm{P}<0.05$ proved insignificant alteration where only one homogenous subset was recorded (Table, 5). Those results 
could be regarded to the fact that aflatoxin is water soluble not oil soluble (Schuller and Van-Egmond, 1983; Wolzak et al.; 1985 and $F D A, 2002)$ so, the residue of aflatoxin in albumin was significant with time and higher in concentration than in egg yolk.

Concerning trichlorfon residues, Table (3) and Fig. (2) demonstrates significant increase $(\mathrm{P}<0.05)$ using ANOVA test and LSD in its concentration in both albumin and yolk of tested eggs till disappeared completely after 7 days.

This result appear to be similar form that recorded by in an experiment in International Programme on Chemical Safety (1991) and in survey by Australian National Residue Survey (1999) where trichlorfon residues was $0.05 \mathrm{mg} / \mathrm{kg}$ in $\mathrm{egg}$.

Maximum residue Limits for trichlorfon in fat, meat and meat byproducts was $0.1 \mathrm{ppm}$ while no tolerance residue level in egg was recorded (EPA, 1999 and $\mathrm{FAO} / \mathrm{WHO}, 2001)$ so presence of trichlorfon in eggs has critical public health significance.

Data analysis of trichlorfon residues in egg albumin using Duncan multiple range test for comparative of means $(\mathrm{P}<0.05)$ indicated gradual drop till disappeared significantly at the $7^{\text {th }}$ day into 3 subsets between $1^{\text {st }}, 2^{\text {nd }} \& 3^{\text {rd }}$ days; $4^{\text {th }}, 5^{\text {th }}$ and $6^{\text {th }}$ days till complete disappearance at last subset ( $7^{\text {th }}$ day) of experiment. Nearly observation was found in egg yolk when subjected to this analysis but the three subsets were in the following manner, firstly $1^{\text {st }}$ and $2^{\text {nd }}$ days then $3^{\text {rd }}, 4^{\text {th }}, 5^{\text {th }} \& 6^{\text {th }}$ days and lastly, $4^{\text {th }}, 5^{\text {th }}, 6^{\text {th }} \& 7^{\text {th }}$ days which was undeletable. This result shows high content of trichlorfon in yolk than albumin plus completely gradual depletion in albumin comparing with yolk could be explained by the fact that the trichlorfon as an organophosphorus pesticide is fat soluble and have a lipophilic capability to yolk which is higher in fat content than albumin (IPCS, 1991; EHC 132; 1992 and Marquardt et al.. 1999) vice versa the obtained aflatoxin pattern.

To answer on a question about role of egg in aflatoxin B1 and trichlorfon excretion, correlation analysis proved that there is significant

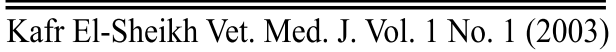


positive correlation $(\mathrm{P}<0.01)$ between presence of aflatoxin $\mathrm{B} 1$ or trichlorfon in albumin and yolk using Pearson correlation test (Table, 8). While negative correlation between concentration of aflatoxin B1 and trichlorfon was observed in albumin (at $\mathrm{P}<0.05)$ and yolk $(\mathrm{P}<0.01)$.

This calculation gives strong evidence on the fact that presence of trichlorfon in hens serum reflected by an increase of aflatoxin in eggs albumin (which are hydrophilic for aflatoxin) than in yolk. Which could be explained increase levels of aflatoxin B1 in both albumin and yolk in this study comparing with some other experiments.

In conclusion, this study proved the danger role plays by egg for human consumption as a site of aflatoxin excretion and presence of pesticide increased accumulation of this toxic material in it. So, withdrawal time must be regarded in uses of pesticide in laying farms and minimization of ration aflatoxin content must be regarded. Also, this study give an evidence on the importance of re-evaluate in the maximum permissible limits of aflatoxin content in laying hens feed as those regarded in milking animal diet.

\section{REFERENCES}

- Abd El-Hamid A.M. and Dorra, T.M. (1990): "Study on effects of feeding laying hens on separate mycotoxin(aflatoxins, patulin,or citrine)contaminated diets on the egg quality and tissue constituents."Arch Tierernahr., 40 (4): 305-316.

- AOAC (1990): "Official Methods of Analysis."15 ${ }^{\text {th }}$ Ed. Association of Official Analytical Chemists, Arlington, VA.

- Australian National Residue Survey, (1999): "Report on the Australian National Residue Survey 1998 Results."Department Of Agriculture, Fisheries and Forestry, Australia, National Office of Food Safety, pp. 44, (C) Commonwealth of Australia 1999, ISBN 0642473609

- Bicchi, C.; D'Amato, A. and Balbo, C. (1997): "Multi-residue Method for Quantitative Gas Chromatographic Determination of Pesticide Residues at .org/pubs/JOURNAL/

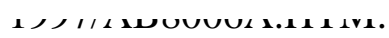

- EHC 132 (1992): "Environmental Health Criteria, 132, Trichlorfon.", 
International Programme of Chemical Safety.

- FAO/WHO(1989):Codex maximum limits for pesticide residues."CAC/Vol .XIII-ed.2, Rome, Codex Alimentarius Commission, Food and Agriculture Organization of the United Nations,-plus Supplement 1(1988) and Supplement 2 (1989).

- FAO/WHO (2001): "Evaluation of certain veterinary drug residues in food." Expert Committee on Food Additives, World Health Organ Tech Rep Ser 2001; 900: i-vi, 1-96

- FDA (2002): "Naturally Occurring Toxins in Foods", (c) Copyright (2002) Purdue University, West Lafayette, Indiana, 47907. All Rights Reserved.

- EPA (1999): "Environmental Protection Agency for currently registered pesticides." APPENDIX IV. U.S. Residue Limits For Pesticides In Meat, Poultry, And Egg Product. Title 40, Part 180 of the Code of Federal Regulations.

- Fernadez, A.; Verde, M.T.; Gascon, M.;Ramos,J.J. and Gomez, J. (1994): "Aflatoxin and its metabolites in tissues from laying hens and broiler chickens fed a contaminated diet." J. Sci. food and Agric., 65 (4): 407.

- Food and Drug Administration Pesticide Program (1997): "Residue Monitoring 1997" pp., 23.

- Fukal,L.and Sova,Z.(1988):"The occurrence of aflatoxin in eggs."Vet.Med, 33 (11): 675-681.

- Hoelscher, C.E. (2000):"Poultry Pesticide Management."Texas Agricultural Extension Service\&Zerle L.Carpenter, Director.The Texas A\&M University System \& College Station, Texas.

- IPCS, International Programme on Chemical Safety (1991): "Health and Safety Guide No.66,(Trichlorfon)."Health and Safety Guide,United Nations Environment Programme, World Health Organization, Geneva 1991.

- Maertlbaner, E., Dietrich, R. and Terplan, G. (1991):"Practical knowledge with the application of immunoassays for the detection of mycotoxins in food." A. R. C.H.-Lebensmittelhyg, 42(1): 3-6. 
- Marquardt, H.; Schafer, S.G.; McClellan, R.O. and Welsch, F. (1999): "Toxicology.", $1^{\text {st }}$ Ed., pp. 744-745, 826-828, 1976, Academic

- Nautiyal, P.C. (2002): "Groundnut : Post-harvest Operations." Chapter XXI, National Research Centre for Groundnut (ICAR), (C FAO.

- Oliveira, CA, Kobashigawa, E. Reis, T.A., Mestieri, L., Albuquerque, R., and Correa, B. (2000): " Aflatoxin B1 residues in eggs of laying hens fed a diet containing different levels of the mycotoxin." Food Addit Contam., 17(6): 459-462.

- Petrie, A. and Watson, P. (1999): "Statistics for Veterinary and Animal Science." $1^{\text {st }}$ Ed., pp. 90-99, 110-115, The Blackwell Science Ltd, United Kingdom.

- Pitt, D. M. (1989): "Field studies on Aspergillus flavus and aflatoxins in Australian ground nuts in aflatoxin contamination of ground nuts." pp. 223., Mcdonald, D. and Mehan, V. K. Eds., India.

- Rossi, S.; Dalpero, A.P.; Ghini, S.; Colombo, R.; Sabatini, A.G. and Girotti, S. (2001): "Multi-residual method for the gas chromatographic analysis of pesticides in honey bees cleaned by gel permeation chromatography." J. Chromatogr. A., 5: 905 (1-2): 223-232.

- Samia, El-Zeini; Eva, R. Farah and Abd El-Kalik, E.M. (2001): "Aflatoxin in egg, liver and gizzard of some Egyptian chickens." J. Egypt. Vet., Med. Ass., 61 (4): 179-186.

- Schuller, P.L and Van Egmond H.P. (1981): "Detection and determination of mycotoxins in food and feed." Workshop on Mycotoxins Analysis. Cairo Sept.9-16.

- Schuller, P.L. and Van-Egmond, H.P. (1983): "Limits and regulation of mycotoxins." Proc. Int. Symp. Mycotoxins 111-124.

- SPSS 11 (2001): "SPSS for windows Release 11.0.1. 27 Oct. 1999." Standard Version, Copyright SPSS Inc., 1989-2001, All Rights Reserved,

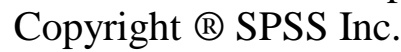

- STATpub.com (1999): "New Tests to Detect Mycotoxins in Grains." A document from STAT Publishing's eStat Project Submitted 02/17/1999.

- Süsse, H. and Müller, H. (1996): "Pesticide analysis by micro cellar electrokinetic capillary chromatography."J.Chromatography.A,730:337-343. 
- Tetushia G. (1990): "Mycotoxins current situation."Food Reviews International, 6 (2): 265- 290.

- USEPA (1999): "United States Environmental Protection Agency, Trichlorfon; Chemical No. 057901." Office Of Prevention, Pesticides And Toxic Substances, August 9, 1999, Washington, D.C. 20460.

- WHO (1992): "World Health Organization, Environmental Health Criteria 132, Trichlorfon." International Programme on Chemical Safety, World Health Organization, Geneva, 1992.

- Worthing, C.R. and Walker, S.B. (1987): "The pesticide manual." $8^{\text {th }}$ ed., Lavenham, Lavenham Press Limited, British Crop Protection Council.

- Wolzak A.; Pearson A.M.;Coleman T.H.;Pestka J.J. and Gray J.I. (1985): "Aflatoxin deposition and clearance in the eggs of laying hens." Food Chem. Toxicol.; 23(12): 1057-1061.

$$
\begin{aligned}
& \text { متبقيات الافلاتوكسين و الترايكلورفون فى بيض الدجاج }
\end{aligned}
$$

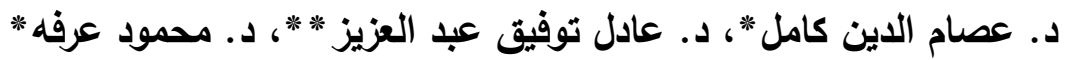

$$
\begin{aligned}
& \text { * قسم الكيمياء - معهد بحوث صحة الحيوان } \\
& \text { * * قم صحة الاغذية - معهد بحوث صحة الحيوان }
\end{aligned}
$$

أجريت هذه الدراسة لتقييم العلاقة بين منتقيات الافلاتوكسين فى بيض الدجاج البياض الذى يتت تغذيته على عليقة

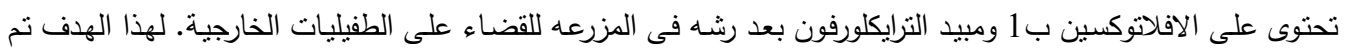

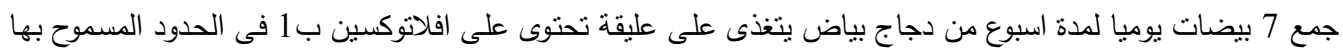

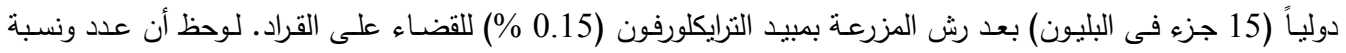

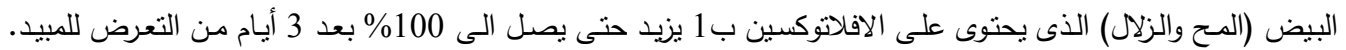
وعلى العكس فأن عدد ونسبة وجود الترايكلورفون فى البيض (المح والزلال) ينخفض تدريجياً حتى يتلاشى تماماً بعد 7 أيام

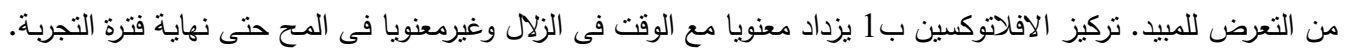

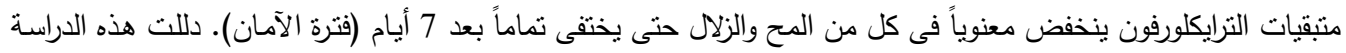

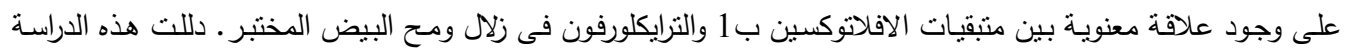

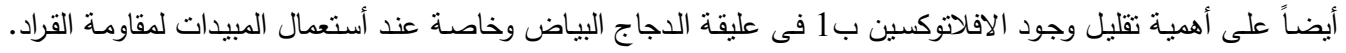

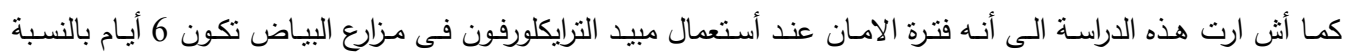

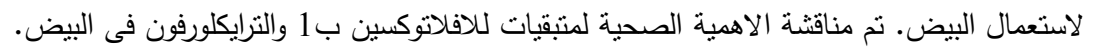

